\title{
Oviposition by the vagrant eriophyoid mite Aculops allotrichus on leaves of black locust tree, Robinia pseudoacacia
}

\author{
Katarzyna Michalska ${ }^{1}$ (D) Anna Tomczyk ${ }^{1}$ (D) - Barbara Łotocka ${ }^{2}$ (D) . \\ Sławomir Orzechowski ${ }^{3}$ (D) Marcin Studnicki ${ }^{4}$ (D)
}

Received: 1 March 2019 / Accepted: 7 August 2019 / Published online: 24 September 2019

(C) The Author(s) 2019

\begin{abstract}
Leaf-dwelling mites often prefer to feed on young leaves and also are more likely to inhabit the abaxial leaf side. The aim of our study was to examine whether leaf age may affect production and distribution of eggs on black locust leaves by females of Aculops allotrichus. The eriophyoids were tested for 2.5 days on 'trimmed' compound leaves (with only two opposite leaflets left), which were maintained in vials filled with water. For the experiments we used leaves of three categories: (1) the 'youngest', in which both halves of the adaxial side of leaflets still adhered to each other (and usually remained folded for the next few hours), (2) 'young' with already unfolded leaflets, and (3) 'mature' with fully expanded leaflets. The tested females laid significantly more eggs on developing leaves than on 'mature' ones, although they deposited the highest number of eggs on the 'young' leaves. The distribution of eggs on adaxial or abaxial leaf sides also depended on leaf age. On the 'youngest' leaves, eriophyoids placed similar numbers of eggs on both sides of a blade. However, the older the leaf, the more willingly females deposited eggs on the abaxial side. Our biochemical and morphometrical analyses of black locust leaves indicated significant changes in the contents of nutrients and phenols within leaf tissue, and in the density of trichomes and thickness of the outer epidermal cell walls, correlated with leaf age. Their possible effects on the production and distribution of eggs on leaves by A. allotrichus are discussed.
\end{abstract}

Keywords Abaxial-adaxial oviposition · Leaf age · Nutrients · Phenols · Leaf trichomes · Outer epidermal wall

Katarzyna Michalska

katarzyna_michalska@sggw.pl

1 Department of Applied Entomology, Faculty of Horticulture, Biotechnology and Landscape Architecture, Warsaw University of Life Sciences, Nowoursynowska 159, 02-776 Warsaw, Poland

2 Department of Botany, Faculty of Agriculture and Biology, Warsaw University of Life Sciences, Nowoursynowska 159, 02-776 Warsaw, Poland

3 Department of Biochemistry, Faculty of Agriculture and Biology, Warsaw University of Life Sciences, Nowoursynowska 159, 02-776 Warsaw, Poland

4 Department of Experimental Design and Bioinformatics, Faculty of Agriculture and Biology, Warsaw University of Life Sciences, Nowoursynowska 159, 02-776 Warsaw, Poland 


\section{Introduction}

For an egg-laying animal, the choice of oviposition site can be a significant component of fitness (Resetarits and Wilbur 1989). This also applies to many phytophagous insects whose juveniles have little chance of changing their place of development. Females are expected to choose the habitat whose features are suitable not only for her, but also those which favour offspring growth and survival (Thomson 1988; Mayhew 1997; Putra et al. 2009; Gall et al. 2012).

For insects and mites that inhabit leaves, decisions regarding oviposition may be influenced by several factors, including (1) the quality and quantity of nutrients, (2) the presence of feeding deterrents (e.g. phenols and tannis) and toxins in leaves (Dąbrowski and Bielak 1978; Awmack and Leather 2002; Bauerfeind and Fisher 2005), and (3) leaf architecture, e.g. thickness of the epidermal cell wall, and the presence of acarodomatia, stomata or trichomes, which may affect food availability for herbivores and also create a specific habitat for them (Hanley et al. 2007; Sudo and Osakabe 2011).

Eriophyoids are tiny $(0.1-0.3 \mathrm{~mm}$ long) herbivorous mites that are highly specialized in relation to their host plants (Keifer 1975; Lindquist et al. 1996; Petanović and Kiełkiewicz 2010b). They often inhabit narrow spaces on plants or induce the growth of galls within which they live. Vagrants are well adapted to living freely on leaves, though they can also seek various leaf depressions or hairs for protection (Keifer 1975; Lindquist et al. 1996; Michalska et al. 2010). In contrast to many leaf-dwelling mites, which clearly prefer the abaxial leaf side, eriophyoids occur either on the abaxial or adaxial or on both sides of a blade and this phenomenon is also species-specific (Keifer 1975; Lindquist et al. 1996; Sudo and Osakabe 2011).

Most eriophyoids have short mouthparts (e.g. Eriophyidae and Phytoptidae), which limit their penetration of plant tissue to the epidermal layers (Keifer 1975; Lindquist and Oldfield 1996). The mites pierce with their stylets through the outer epidermal cell wall, inject saliva and finally suck out the externally digested cell content (Nuzzaci and Alberi 1996). However, gall-formers and some vagrant species can also derive food from deeper layers, via the nutritive tissues that originate from epidermal and mesophyll cells during feeding (Westphal and Manson 1996; Petanović and Kiełkiewicz 2010a).

In contrast to the inner periclinal and anticlinal walls, the outer epidermal cell wall is especially thick and it becomes even thicker with leaf age (Segado et al. 2016). The cuticle, the hydrophobic region of the outer epidermal cell wall (Fernández et al. 2016), together with epicuticular waxes, can considerably hinder the feeding of insects and mites as well as their movement and attachment to the leaf surface (Gibson 1974; Gutschick 1999; Ochoa et al. 2011; Bensoussan et al. 2016; Gorb and Gorb 2017; Wójcicka 2016).

As shown by the survey of 36 angiosperm species, including herbaceous, woody deciduous or woody evergreen plants (Onoda et al. 2015), the thickness of the outer epidermal cell wall (including a cuticle layer) of leaves ranges from a few up to $30 \mu \mathrm{m}$, depending on the plant species. For comparison, in most species of eriophyoid mites, the length of chelicerae lies between 15 and $40 \mu \mathrm{m}$ (except for some eriophyoids from Nalepellidae and most species from Rhyncaphytoptidae in which the length of chelicerae can reach 60-70 $\mu \mathrm{m}$ ) (Keifer 1975). This suggests that the outer epidermal cell wall may be a significant barrier to eriophyoid feeding, and further investigations are needed to determine how long eriophyoid chelicerae are in relation to the thickness of the outer epidermal cell wall of their host plants, and whether these parameters are correlated. 
Apart from the outer cell wall of epidermis or epicuticular waxes, leaf trichomes can also substantially impede herbivore feeding (Gutschick 1999; Hanley et al. 2007; Dalin et al. 2008), mechanically affecting herbivore attachment to the leaf surface, or being an irritant to their bodies. Glandular trichomes, on the other hand, produce sticky and/or toxic substances that can act lethally or sub-lethally on herbivorous insects and mites (Stipanovic 1983; Chatzivasileiadis and Sabelis 1997; Gutschick 1999; Xiao et al. 2017). However, for many tiny arthropods, such as mites, leaf pubescence can also be beneficial; leaf trichomes can protect them against predators, create a favourable microclimate, and catch pollen and hyphae for fungi and pollen-feeders (Kreiter et al. 2002; Sudo and Osakabe 2011).

Leaf architecture can differ considerably between adaxial (upper) and abaxial (lower) leaf sides (Sudo and Osakabe 2011). It can also change with leaf age (Coetzee et al. 2009; Fernández et al. 2014), so does the content of nutrients and secondary compounds within a single leaf (Gutshick 1999). Thus, the environment within the same leaf can be diverse and will vary with time, which may also affect the behaviour of arthropods inhabiting leaves in different ways (Sudo and Osakabe 2011).

Eriophyoid mites have been recorded on both young and old leaves. Many eriophyoid species clearly prefer to colonize young leaves rather than old ones (Keifer 1975; Lindquist et al. 1996). Gall formers require meristem tissue to induce the growth of galls (Nalepa 1928; Keifer 1975). Several free-living species, e.g. Acaphylla cajani (Channabasavanna 1996), Calepitrimerus vitis (Duso and de Lillo 1996), Aculus fockeui (Castagnoli and Oldfield 1996) and Abacarus hystrix (Keifer 1975), are also reported as preferring to build up populations on plant's new growth. Other eriophyoids, however, such as Phyllocoptruta oleivora (Keifer 1975), Acaphyllisa parindiae or Calacarus carinatus (ChannaBasavanna 1996) clearly favour mature leaves to developing leaves. It is still not clear what effects leaf architecture, as well as different nutrients and feeding deterrents in young vs. old leaves, might have on eriophyoid decisions about settlement and egg laying on leaves.

The aim of our study was to examine the effect of leaf age on oviposition by Aculops allotrichus Nalepa, a vagrant eriophyoid that inhabits compound leaves of the black locust tree, Robinia pseudoacacia L. (Castagnoli and Laffi 1985; Amrine and Stasny 1994). The eriophyoid and its host plant constitute an interesting study system. Aculops allotrichus can be noted on both abaxial and adaxial sides of leaflets, although on mature leaves it markedly prefers the abaxial side. The leaves of the black locust tree are reported to contain various secondary compounds, including phenols, terpenoids and steroids (Hosseinihashemi et al. 2016; Madanat et al. 2018; Kaloo et al. 2018), as well as two toxins, robin and robitin (present mostly in young leaves), which are known to be poisonous to humans and livestock (Levis and Elivin-Lewis 2003). Both sides of the leaves are covered by non-glandular, uniseriate, one or three-cellular trichomes (Orlović et al. 2004; Călina et al. 2011).

Apart from the production and distribution of eggs by A. allortrichus females, we also analysed some factors that could affect their oviposition on leaves of different ages. (1) We estimated the content of some essential nutrients and secondary compounds in the leaf tissue i.e. soluble proteins, sugars, and amino acids as well as phenols. (2) We compared the length of stylets of females and larvae and the thickness of the outer epidermal cell wall of the abaxial and adaxial leaf sides, which could be a potential feeding barrier for females and their offspring. (3) As leaf pubescence could favour the survival of eriophyoids, we also compared the density of those trichomes on both sides of leaflets. 


\section{Materials and methods}

Aculops allotrichus females were collected from an infested tree of black locust, $R$. pseudoacacia grown on the campus of the Warsaw University of Life Science. All tests, including morphometric and biochemical analysis, were carried out using 'clean' compound leaves. These were obtained from a group of six non-infested black locust shrubs grown in full sunshine, at a distance of 1-2 m from each other in the Ursynów district, Warsaw. We used 'clean' leaves of three categories: (1) the 'youngest', 4th-9th top compound leaves in which the adaxial blades of both halves of leaflets adhered to each other along the main vein and became unfolded within a few hours of the test, (2) 'young', 5th-11th top compound leaves with already unfolded leaflets, and (3) 'mature', 6th-15th top compound leaves with fully expanded leaflets. From each black locust shrub we collected 3-4 compound leaves of each category. The sampled leaves were transported to the laboratory in a portable refrigerator at a temperature of $5-10{ }^{\circ} \mathrm{C}$. Handling eriophyoids, counting eriophyoid eggs and leaf trichomes were carried out at $\times 25-50$ magnifications, under an Olympus SZX zoom stereomicroscope equipped with a source of cool light, Olympus Highlight 3100 . Eriophyoids were manipulated using an eye-lash glued to a wooden stick.

\section{Effect of leaf age and leaf side on eriophyoid oviposition}

For the test, we collected $\mathrm{N}=19$ 'clean' compound leaves of each category that were then 'trimmed', i.e., only two, the lowest and opposite bottom-leaflets were left, whereas the other leaflets, together with the rachis, were cut off. Each 'trimmed' leaf was placed in a vial filled with water and sealed from above with a plasticine cap, which secured the vials from water loss.

Tests were conducted at $26^{\circ} \mathrm{C}$ and $16 / 8 \mathrm{~L} / \mathrm{D}$ photoperiod. On each trimmed compound leaf, three randomly selected eriophyoid females of $A$. allotrichus were placed. Females were put on the adaxial side of any of two leaflets except for the youngest leaves, which were folded at the beginning of the test, therefore females were placed on their abaxial sides. Eriophyoids were placed on leaves in the afternoon. After 2.5 days they were removed and the eggs on both sides of the leaflets were counted.

\section{Eriophyoid stylets and body lengths}

The following measurements were carried out in order to compare the length of stylets of females of A. allotrichus and their youngest offspring in relation to their body length. Eriophyoid larvae and females were randomly chosen from infested leaves of the black locust, placed laterally in a drop of Heinze-PVA medium (Evans 1992) and then covered by a coverslip and cleared. For the measurement of chelicerae, larvae $(\mathrm{N}=69)$ and females $(\mathrm{N}=71)$ were put laterally on microscopic slides, whereas for the measurement of body length larvae $(\mathrm{N}=53)$ and females $(\mathrm{N}=60)$ were placed dorso-ventrally on slides. Measurements were conducted under a phase-contrast microscope (Olympus CX41) with the aid of Color View III CCD Camera and Olympus Soft Imaging System (SIS), Cell ${ }^{\mathrm{B}}$.

The gnathosoma of eriophyoids forms a set of stylets, which are enclosed within the longitudinal groove of the rostrum, the so-called rostral gutter (Lindquist 1996). The stylet complex consists of a pair of chelicerae, a pair of auxiliary stylets, which are as long as chelicerae, and a much shorter, oral stylet. At the bases of the chelicerae, there is a small, knob-like structure, a so-called motivator, which enables the 
movement of chelicerae during feeding (Lindquist 1996). On microscopic slides, eriophyoid stylets came out from the rostral gutter and often remained stuck together. The chelicerae were enlarged at their bases and together with the motivator formed a clear protrusion at the basal part. For each eriophyoid, the total length of the complex of stylets was measured once, starting from the end of the protrusion at their basal part (together with the motivator) up to their sharply ended tips. Similarly, to estimate eriophyoid body length, sampled larvae and females were measured once, beginning from the ends of their opististosomae to the tips of their rostra.

\section{Effect of leaf age and side on trichome density and outer wall thickness of epidermal cells}

For each measurement, 20 bottom-leaflets of each leaf category were sampled from collected compound leaves, and a rectangular leaf piece was cut off from the middle part of each leaflet using a razor blade. The leaf strip was either $4 \mathrm{~mm}$ (measurement of leaf trichome density) or $2 \mathrm{~mm}$ (measurement of wall thickness of epidermis cells) wide and included the blade of one half of a leaflet, the main vein and a small fragment of a blade of the other half of the leaflet. The measurements were carried out for both the adaxial and abaxial leaf sides.

To estimate leaf trichome density, the vein was cut from the blade and the contour of the rectangular piece of a blade was drawn on graph paper. After surface measurement, both a blade strip and a piece of the vein were placed in a vial with $50 \%$ ethanol, in which they were stored for the time of trichome counting. The density of trichomes was then estimated per $1 \mathrm{~mm}^{2}$ of a blade and for a 4-mm-long segment of the vein.

The 'wall thickness' of epidermal cells was measured as the total thickness of the outer wall and cuticle layer. For this measurement, leaf strips were individually fixed in a mixture of $5 \%$ glutaraldehyde and $4 \%$ paraformaldehyde in a $0.1 \mathrm{M} \mathrm{Na-cacodylate}$ buffer, $\mathrm{pH} 7.2$, for $12 \mathrm{~h}$ under an air pressure of $-0.06 \mathrm{MPa}$ at room temperature. Samples were rinsed in the same buffer repeatedly during the next few days, dehydrated in a graded ethanol series and stored in ethanol 50\% until embedding. Next, the samples were embedded in a glycid ether 100 epoxy resin (SERVA) grade hard, which was prepared and polymerized according to the manufacturer's formula.

Ultra-thin sections were cut using Ultracut E microtome (Reichert), placed on slotgrids coated with Formvar (SERVA), and contrasted with $1.2 \%$ uranyl acetate in $70 \%$ methanol for 20 min followed by Reynolds's lead citrate for $30 \mathrm{~min}$. The ultrastructure was observed by means of a Morgagni 268D transmission electron microscope (TEM) (FEI Company) operating at $80 \mathrm{kV}$. Images of the epidermal cells were saved as $3241 \times 2588$ pixel tiff files using digital camera Morada (SIS) operating under iTEM software (SIS).

The measurements of thickness of the epidermal cell walls were made on epidermis TEM images using $\mathrm{Cell}^{\mathrm{B}}$ software (Olympus SIS). For each leaf category, images from $\mathrm{N}=4$ leaf strips were taken. The outer wall thickness of both adaxial and abaxial epidermis cells was measured in, in total, 1091 cells per leaf blade, and 572 cells per main vein. Due to high variation in outer wall thickness of a single cell, two measurements were made close to the mid-point of the outer cell wall, and the averaged values were taken for statistical analysis. 


\section{Effect of leaf age on the content of nutritive compounds and phenols in leaves}

Two samples of compound leaves of each category $(\mathrm{N}=20)$ were collected for analysis. In the first leaf sample the content of amino acids was estimated, whereas in the second one, the content of proteins, carbohydrates, dry matter and phenols was measured. Leaf samples were put into foil bags and soon after arrival in the laboratory they were placed into a freezer at $-70{ }^{\circ} \mathrm{C}$ where they were stored until the analysis started. The concentration of all compounds was estimated in $\mathrm{mg}$ per $\mathrm{g}$ fresh weight using the spectrophotometric method. The analysis of amino acids was done in four replications, and proteins, carbohydrates and phenols in five replications.

\section{Measurement of the content of amino acids}

The measurement of the content of amino acids was carried out according to the Lie (1973) method. A total of $100 \mathrm{mg}$ leaf tissue was ground with $1 \mathrm{ml}$ deionized water using a mortar and pestle. The mortar was washed with another $1 \mathrm{ml}$ of deionized water, which was added to the triturated tissue. The obtained crude extract was vortexed $(200 \mathrm{rpm})$ for $30 \mathrm{~min}$ at room temperature. Then samples were centrifuged for $20 \mathrm{~min}$ at $10,000 \mathrm{rpm}$ at room temperature. Next the supernatants were collected in new tubes precooled on ice. $250 \mu \mathrm{l}$ of such an obtained leaf sample (or $10 \times$ diluted $0.1 \%$ glycine standard solution in deionized water) was mixed with $750 \mu \mathrm{l}$ deionized water and $500 \mu \mathrm{l}$ of ninhydrin solution $(0.5 \%$ ninhydrin in $0.1 \mathrm{M}$ potassium-phosphate buffer $\mathrm{pH} 6.8$, solution was stored in a dark bottle at $4{ }^{\circ} \mathrm{C}$ for no longer than 1 week). The colour solution was mixed for $10 \mathrm{~s}$, heated at $100{ }^{\circ} \mathrm{C}$ for $16 \mathrm{~min}$, and cooled for $2 \mathrm{~min}$ in an ice-bath. Then, the samples were centrifuged for $10 \mathrm{~min}$ at $10,000 \mathrm{rpm}$ at room temperature. After centrifugation $2.5 \mathrm{ml}$ of ethyl alcohol was added, the samples were vortexed for $10 \mathrm{~s}$, then incubated for $15 \mathrm{~min}$ at room temperature. Absorbance was read at $570 \mathrm{~nm}$ against a reference sample made from the reagents and deionized water using Spectroquant Pharo 300 (Merck, Germany). The content of amino acids was calculated using glycine (cat. no. 3187.1, Carl Roth, Germany) as a standard.

\section{Measurement of the content of proteins, carbohydrates, dry matter and phenols}

For estimation of the content of soluble proteins, reducing sugars, total soluble sugars and phenols from each leaf age category, samples of $50 \mathrm{mg}$ plant material were taken. The analysis of each compound was performed in five replications. The plant material was grounded in solutions suitable for the determination of the analyzed substances. The homogenates were centrifuged for $15 \mathrm{~min}$ at $6000 \mathrm{rpm}$ for proteins or at $10,000 \mathrm{rpm}$ for sugars and phenols. The measurements were carried out using a UV-1202 Shimadzu spectrophotometer UV-VIS.

The amount of soluble proteins was estimated according to the Bradford method (Bradford 1976). Leaves were homogenized with a $0.1 \mathrm{M}$ phosphoric buffer, $\mathrm{pH}$ 7.0. The phosphoric buffer extract $(0.1 \mathrm{ml})$ was mixed with $5 \mathrm{ml}$ of Bradford reagent (Sigma B 6916) and left for $10 \mathrm{~min}$ before measurements. The extinction was read at $595 \mathrm{~nm}$. Bovine albumin (Sigma A 2153) was used to prepare a standard curve.

For estimation of the total amount of soluble sugars, leaf samples were homogenized with distilled water. The supernatants $(1 \mathrm{ml})$ were used for reaction with Antrone Reagent (Sigma 319899), according to the antron method described by Yemen and Willis (1954). 
The sugar solution was kept for $10 \mathrm{~min}$ at $90{ }^{\circ} \mathrm{C}$ with $5 \mathrm{ml}$ of Antrone Reagent. The extinction of the mixture after reaction was read at $620 \mathrm{~nm}$. The content of total soluble sugars was calculated using glucose (Sigma G 8270) as a standard.

The concentration of reducing sugars was estimated according to the Nelson (1994) method. The supernatants that were prepared from each group of leaves were diluted with distilled water, and $1 \mathrm{ml}$ of extract was taken for reaction with cupric and arsenomolibdenic reagents according to the Nelson procedure. After $20 \mathrm{~min}$ of reaction in boiling water, the extinction of the mixture was read at $520 \mathrm{~nm}$. Reducing sugar concentration was calculated using glucose as a standard.

Total phenol content was estimated according to the Johnson and Schaal (1957) method. The leaf samples were homogenized in $80 \%$ methanol at a low temperature $\left(2-4{ }^{\circ} \mathrm{C}\right)$ and left in the refrigerator for $24 \mathrm{~h}$. After centrifugation supernatants were taken for reaction with Folin-Ciocalteu's phenol reagent (Sigma-Aldrich F 9252). One h after reaction the extinctions of the mixtures were read at $725 \mathrm{~nm}$. The content of total phenols was estimated on the basis of a standard curve prepared for chlorogenic acid (Sigma C 3878).

To estimate dry matter content in the leaves, leaf samples were placed in glass weighing vessels, weighed and transferred to a dryer at $105{ }^{\circ} \mathrm{C}$ for $24 \mathrm{~h}$. Then the sample vessels were re-weighed. From the ratio between dry and fresh leaf mass, the percentage of dry matter content in the leaf samples was calculated.

\section{Statistical analysis}

For analysis of the effects of a leaf side (adaxial or abaxial) and leaf age ('youngest', 'young' or 'mature') on the number of eggs, generalized linear model (GLM) with Poisson error distribution and log link function was used. To test pairwise comparisons between treatments, Tukey contrasts were applied. Observations of the length of A. allotrichus chelicerae were analysed using Student's t-test. The wall thickness of epidermis cells and trichome densities were analysed using two-way ANOVA, whereas the effect of leaf age on nutrient and phenol contents was evaluated by one-way ANOVA. We determined differences among factor levels in ANOVA models using Tukey's HSD post hoc test. Trichome densities and wall thickness leaf effect were included, as a block, in the analysis of egg numbers. Statistical analysis was performed using R v.3.3.2 software (R Development Core Team 2016).

\section{Results}

\section{Effect of leaf age on eriophyoid oviposition}

The total number of eggs deposited by females on leaves was influenced by the age of a leaf $\left(\chi^{2}=124.35, \mathrm{df}=2, \mathrm{P}<0.0001\right)$. The greatest number of eggs was produced on the young leaves (Fig. 1). A significantly lower number of eggs was laid on the youngest leaves, whereas the lowest egg number was deposited on the mature leaves.

The egg distribution was affected by leaf blade side $\left(\chi^{2}=35.479\right.$, $\left.\mathrm{df}=1, \mathrm{P}<0.0001\right)$, leaf age $\left(\chi^{2}=122.35, \mathrm{df}=2, \mathrm{P}<0.0001\right)$ and their interaction $\left(\chi^{2}=81.315, \mathrm{df}=2\right.$, $\mathrm{P}<0.0001$ ). On the youngest leaves, females laid a similar number of eggs on the abaxial and adaxial sides of the leaf blade, whereas on the older leaves (young and mature ones) females placed significantly more eggs on the abaxial than on the adaxial side (Fig. 2). 


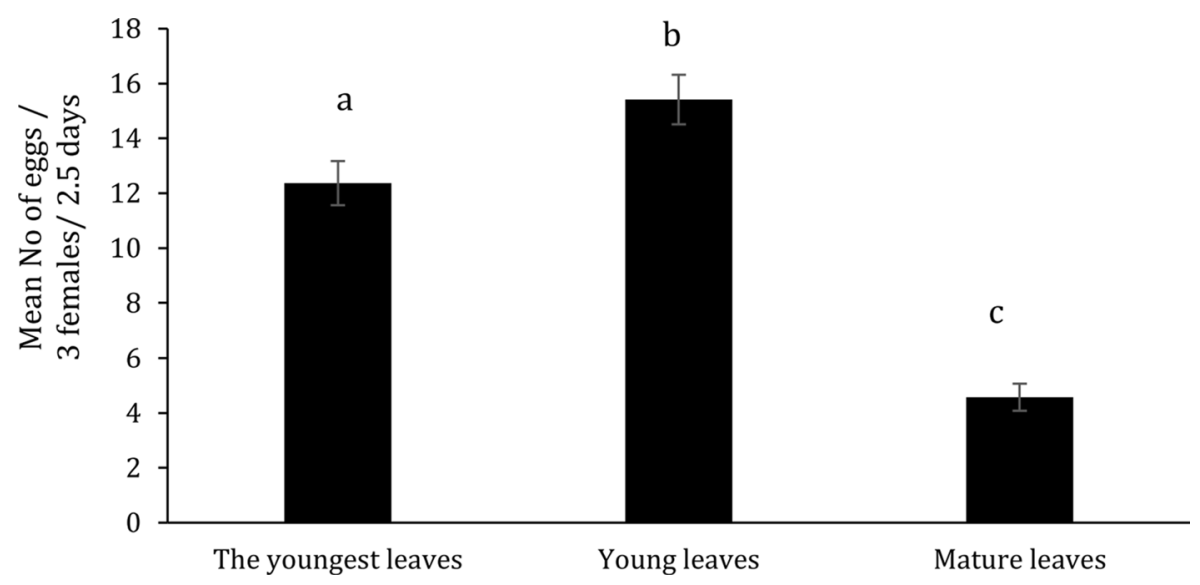

Fig. 1 Mean $( \pm \mathrm{SE})$ number of eggs produced by Aculops allotrichus on leaflets of 'trimmed' youngest, young and mature compound leaves of Robinia pseudoacacia. Bars marked with different letters are significantly different (Tukey's test: $\mathrm{P}<0.05$ )

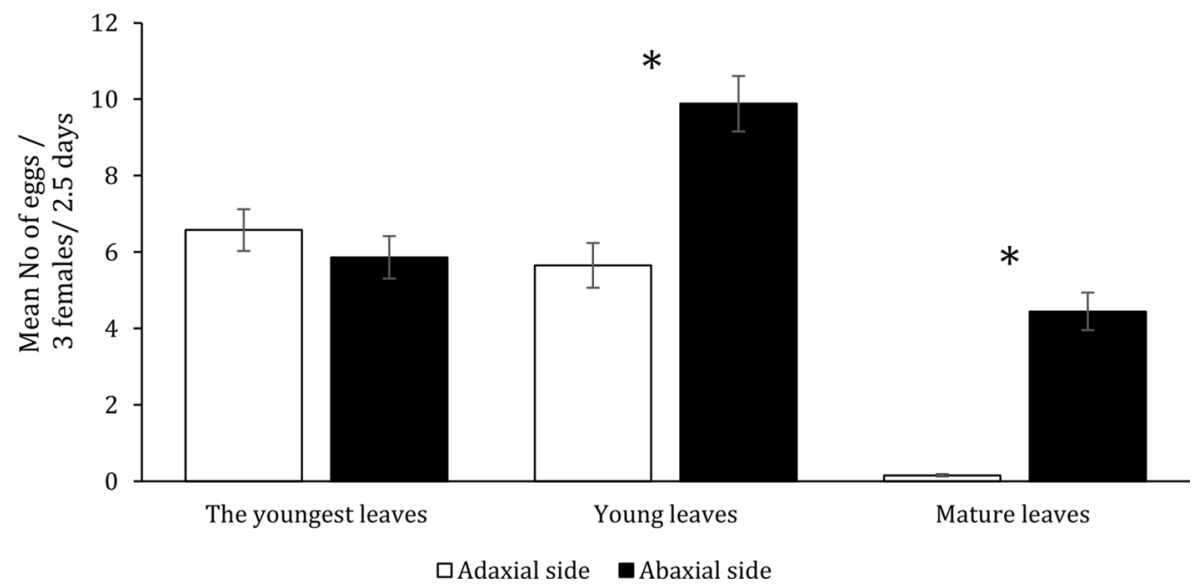

Fig. 2 Distribution of [mean $( \pm \mathrm{SE})$ number of] eggs by Aculops allotrichus on the abaxial and adaxial sides of leaflets of 'trimmed' youngest, young and mature compound leaves of Robinia pseudoacacia. $* \mathrm{P}<0.05$

\section{Effect of leaf age on the content of nutritive compounds, phenols and dry matter in leaves}

Analysis of variance revealed the significant effect of leaf age on the content of amino acids, soluble proteins, total soluble sugars, phenols and dry matter in fresh leaves (Table 1). As shown in Table 2, only the content of reducing sugars was similar in all leaf age classes. In contrast to the youngest and mature leaves, the young leaves contained the highest concentration of total soluble sugars. Concentrations of soluble proteins did not differ significantly between the young and mature leaves, though they were much higher in the young than in the youngest leaves. Both the young and youngest leaves contained 
Table 1 One-way ANOVA for the effect of leaf age on the content of nutritive compounds, phenols and dry matter in leaves of Robinia pseudoacacia

\begin{tabular}{lrrrl}
\hline Factor & \multicolumn{1}{l}{ SS } & \multicolumn{1}{l}{ MS } & \multicolumn{1}{c}{$\mathrm{F}_{2,12}$} & $\mathrm{P}$ \\
\hline Total soluble sugars & 137.95 & 68.97 & 12.54 & 0.0025 \\
Reducing sugars & 2.43 & 1.22 & 0.96 & 0.42 \\
Soluble proteins & 3.72 & 1.86 & 46.88 & 0.00002 \\
Amino acids & 40.89 & 20.45 & 18.65 & 0.00063 \\
Phenols & 24.51 & 12.26 & 17.25 & 0.00083 \\
Dry matter & 52.27 & 26.14 & 4.55 & 0.043 \\
\hline
\end{tabular}

Table 2 Mean $( \pm \mathrm{SE})$ content of nutritive compounds and phenols (mg/g fresh leaf mass) and mean $\%$ dry matter in the youngest, young and mature leaves of Robinia pseudoacacia

\begin{tabular}{lrrr}
\hline Compounds & Youngest leaves & Young leaves & Mature leaves \\
\hline Total soluble sugars & $21.44 \pm 1.30 \mathrm{a}$ & $26.70 \pm 1.30 \mathrm{~b}$ & $17.55 \pm 1.30 \mathrm{a}$ \\
Reducing sugars & $6.30 \pm 0.46 \mathrm{a}$ & $5.75 \pm 0.46 \mathrm{a}$ & $6.90 \pm 0.46 \mathrm{a}$ \\
Soluble proteins & $1.32 \pm 0.09 \mathrm{a}$ & $2.44 \pm 0.09 \mathrm{~b}$ & $2.48 \pm 0.09 \mathrm{~b}$ \\
Amino acids & $8.16 \pm 0.52 \mathrm{a}$ & $6.78 \pm 0.52 \mathrm{a}$ & $3.74 \pm 0.52 \mathrm{~b}$ \\
Phenols & $8.04 \pm 0.50 \mathrm{a}$ & $8.68 \pm 0.50 \mathrm{a}$ & $4.94 \pm 0.50 \mathrm{~b}$ \\
Dry matter & $28.50 \pm 1.20 \mathrm{a}$ & $24.68 \pm 1.20 \mathrm{~b}$ & $23.65 \pm 1.20 \mathrm{~b}$ \\
\hline
\end{tabular}

Means within a row marked with different letters are significantly different at $\mathrm{P}<0.05$

significantly higher concentrations of amino acids and phenols than the mature leaves, whereas the contents of these compounds did not differ significantly between the young and the youngest leaves. The young leaves had a similar percentage of dry mass to the mature leaves. The percentage of dry mass in these leaves, however, was significantly lower than in the youngest leaves.

\section{Effect of leaf age and side of leaf blade on trichome density and the wall thickness of epidermal cells}

On a leaf blade, trichome density was influenced by the age of a leaf $\left(\mathrm{F}_{2,9}=38.910\right.$, $\mathrm{P}<0.0001)$ and leaf side $\left(\mathrm{F}_{1,9}=1.274, \mathrm{P}=0.032\right)$, whereas the interaction between leaf age and leaf side was non-significant $\left(\mathrm{F}_{2,9}=0.263, \mathrm{P}=0.31\right)$. Similarly, leaf age $\left(\mathrm{F}_{2,9}=\right.$ 156.3979, $\mathrm{P}<0.0001)$ and leaf side $\left(\mathrm{F}_{1,9}=7.275, \mathrm{P}<0.0001\right)$ affected trichome density on a main vein, whereas the interaction between leaf age and leaf side was non-significant $\left(\mathrm{F}_{2,9}=0.482, \mathrm{P}=0.10\right)$.

As shown in Fig. 3a, b, the density of trichomes was the greatest on the youngest leaves and decreased significantly in young and mature leaves both on a blade and main vein. Trichome density was also significantly greater on the abaxial than adaxial side of a leaf except for the blade of the mature leaves (Fig. 3a), on which there were no significant differences between trichome densities on either side.

The analysis of variance revealed that outer wall thickness of leaf epidermal cells also strongly depended on leaf age and adaxial or abaxial leaf side. In the cells of a leaf blade, wall thickness was affected by the age of a leaf $\left(\mathrm{F}_{2,9}=46.656, \mathrm{P}<0.0001\right)$, leaf side $\left(\mathrm{F}_{1,9}=40.334, \mathrm{P}<0.001\right)$ and their interaction $\left(\mathrm{F}_{2,9}=4.919, \mathrm{P}=0.036\right)$. Similarly, 

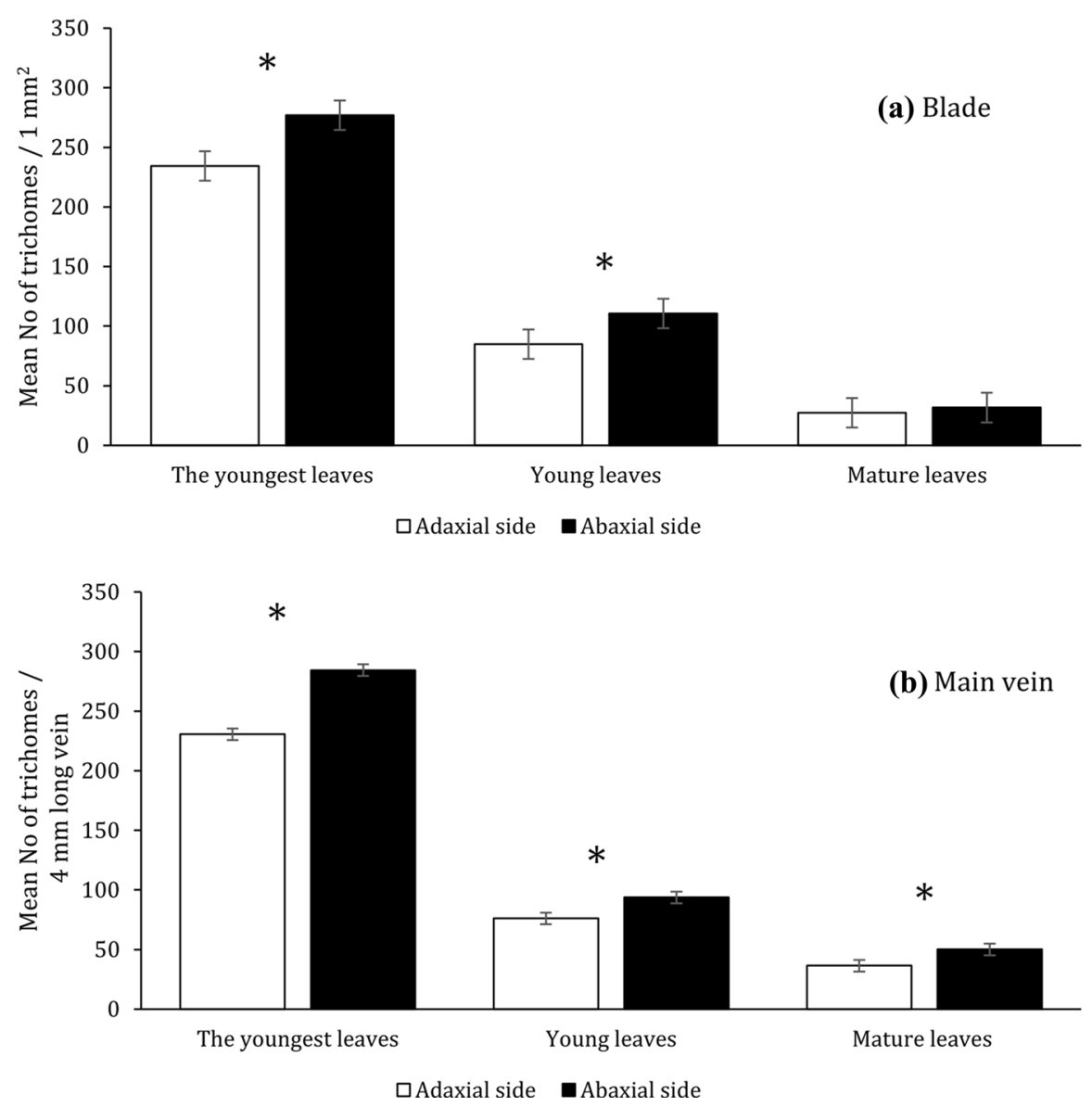

Fig. 3 Mean $( \pm$ SE) density of trichomes covering $\mathbf{a}$ blade and $\mathbf{b}$ main vein of the adaxial and abaxial sides of leaflets of the youngest, young and mature compound leaves of Robinia pseudoacacia. $* \mathrm{P}<0.05$

the effect of leaf age $\left(\mathrm{F}_{2,9}=145.994, \mathrm{P}<0.0001\right)$, leaf side $\left(\mathrm{F}_{1,9}=94.574, \mathrm{P}<0.0001\right)$ and their interaction $\left(\mathrm{F}_{2,9}=15.587, \mathrm{P}=0.001\right)$ were significant in main veins.

On average, the cells of a blade epidermis possessed much thinner outer walls than the epidermis cells of a main vein, and were $0.58 \pm 0.07 \mu \mathrm{m}$ (mean $\pm \mathrm{SE}$; $\min -\max =0.24-1.26)$ and $1.21 \pm 0.20 \mu \mathrm{m}(\min -\max =0.45-2.71)$, respectively $\left(\mathrm{F}_{2,46}\right.$ $=6.05, \mathrm{P}=0.0002$ ). Both in veins and blades the cell wall thickness of the abaxial or adaxial epidermis differed significantly among all leaf classes and clearly increased with leaf age (Figs. 4, 5). In a vein, the cell wall was thicker in the abaxial than in the adaxial epidermis; however, the magnitude of these differences also depended on leaf age. In the youngest leaves, there were no differences in wall thickness (Fig. 4a). However, as the leaf age increased, the cell wall of the abaxial epidermis of the vein became thicker than that of the adaxial one (Fig. 5e, f). In contrast to the vein, the outer cell wall of the 

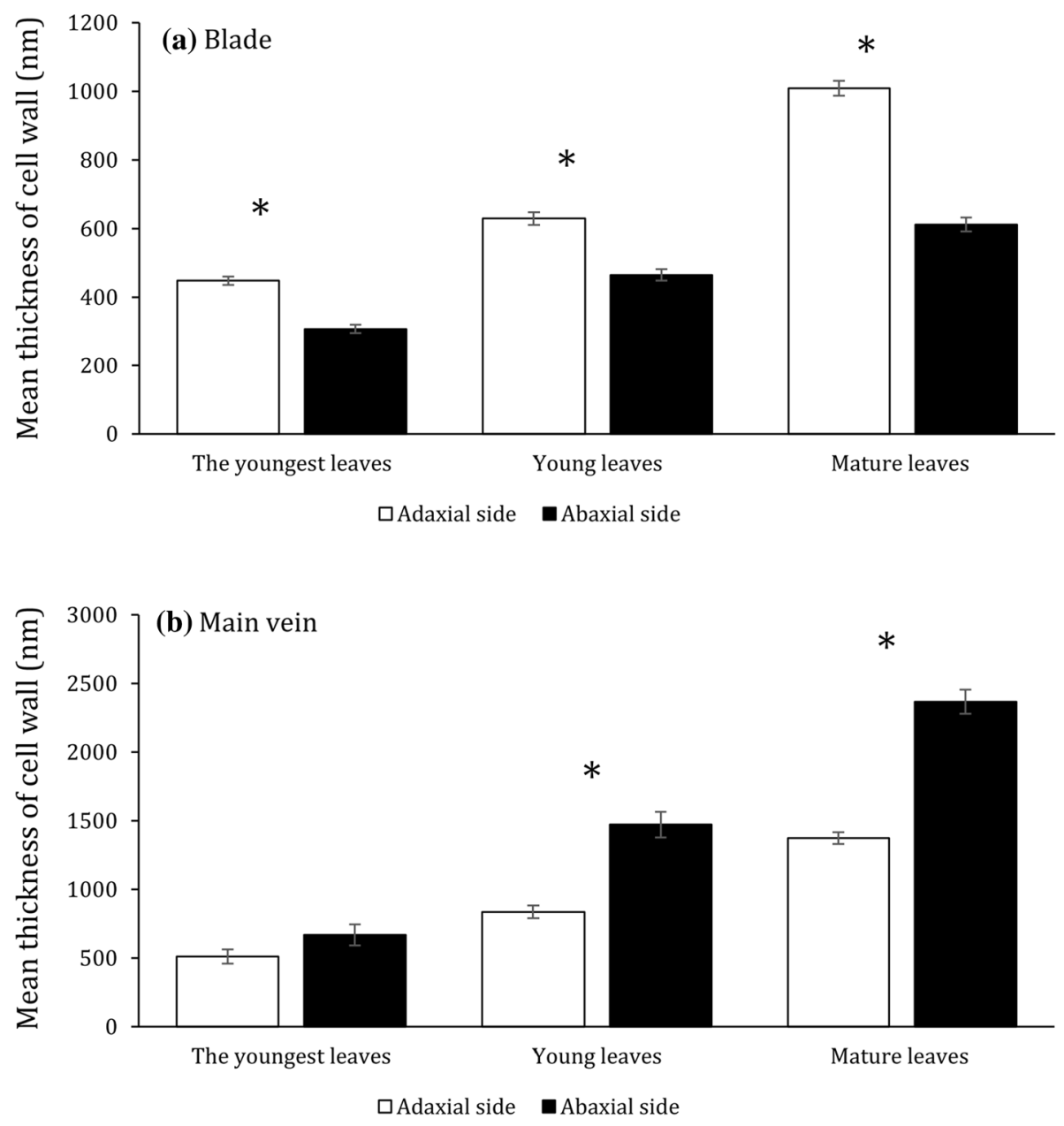

Fig. 4 Mean $( \pm S E)$ thickness $(\mathrm{nm})$ of the outer epidermal cell wall of the adaxial and abaxial side of leaflets of the youngest, young and mature compound leaves of Robinia pseudoacacia. ${ }^{*} \mathrm{P}<0.05$

blade adaxial epidermis was thicker than that in the abaxial epidermis, and the difference was greatest in the mature leaves (Figs. 4b, 5a-d).

\section{Stylets and body lengths in females and larvae}

Females and larvae differed in their body lengths (Student's t-test: $t=93.259$ ) and the lengths of stylets $(\mathrm{t}=27.348$, both $\mathrm{P}<0.0001)$. Nonetheless, in contrast to body length, differences in stylet length between larvae and females were quite small (Table 3; Fig. 6). This was also reflected in a much lower proportion of stylet length to body length in larvae than in females. 


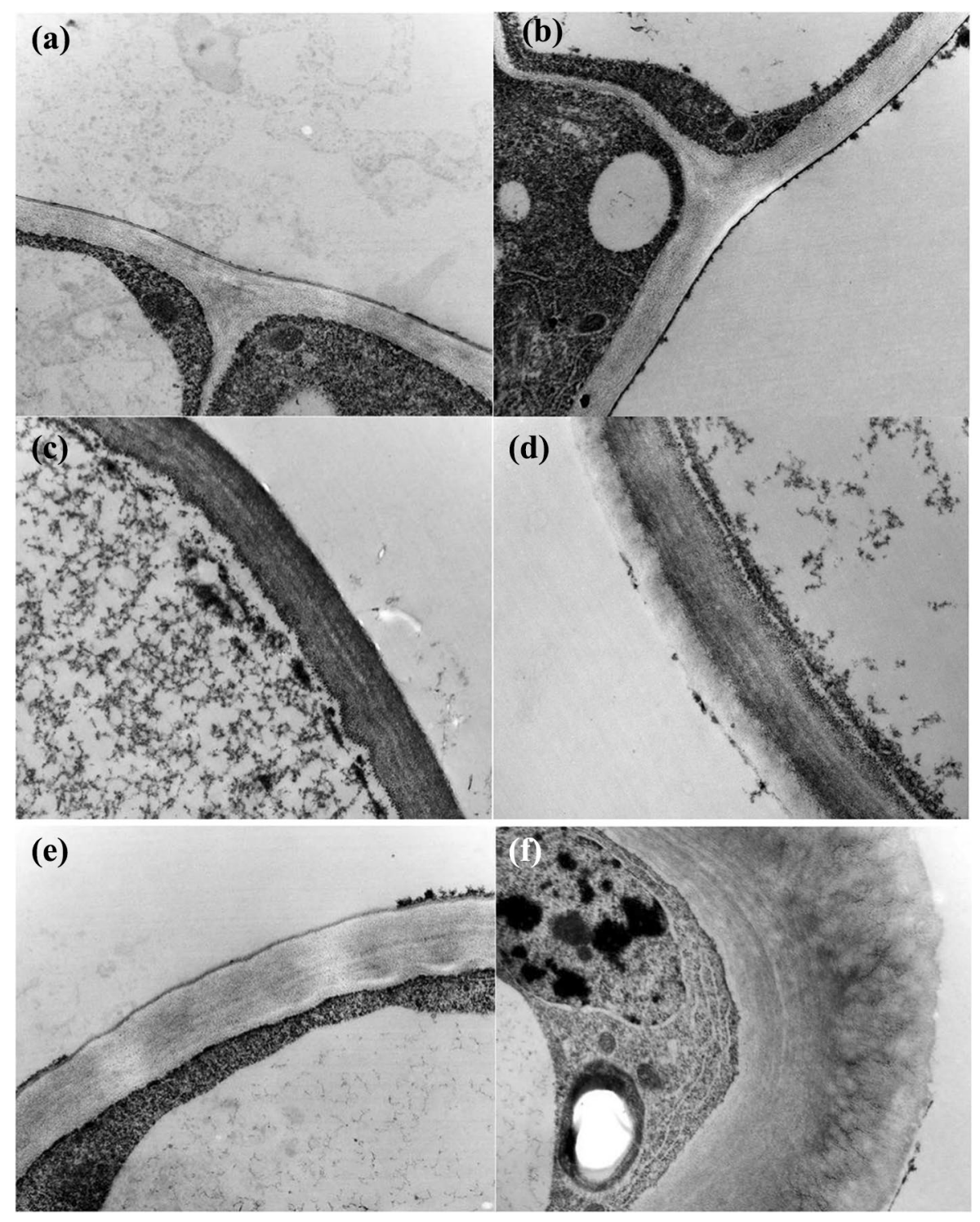

Fig. 5 TEM pictures of the epidermal outer cell wall cross sections of Robinia pseutoacacia leaf blade (ad) and vein $(\mathbf{e}-\mathbf{f})(\times 14,000)$. Abaxial $(\mathbf{a}, \mathbf{c})$ and adaxial $(\mathbf{b}, \mathbf{d})$ side of the blade epidermis of the youngest leaves $(\mathbf{a}, \mathbf{b})$ and mature leaves $(\mathbf{c}, \mathbf{d})$. Abaxial side of the vein epidermis of the youngest $(\mathbf{e})$ and mature (f) leaves

Table 3 Mean $( \pm$ SE) stylet and body lengths $(\mu \mathrm{m})$ and their proportions in females and larvae of Aculops allotrichus

\begin{tabular}{llll}
\hline Eriophyoid stage & Stylet length & Body length & $\begin{array}{l}\text { Proportion of stylets } \\
\text { length to body length }\end{array}$ \\
\hline Larva & $17.28 \pm 0.12$ & $88.58 \pm 0.73$ & $1: 5$ \\
Female & $23.45 \pm 0.19$ & $205.3 \pm 1.02$ & $1: 9$ \\
\hline
\end{tabular}



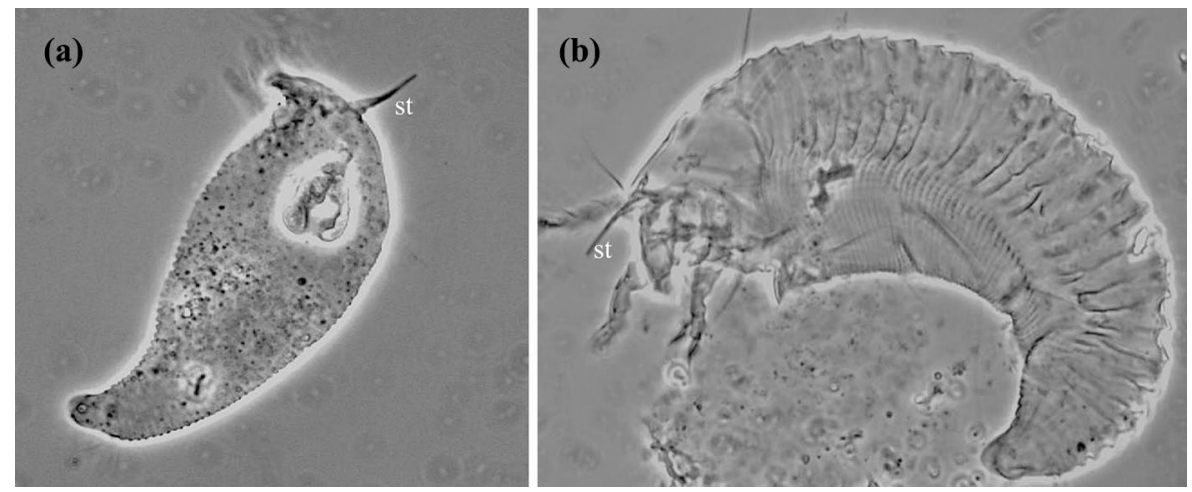

Fig. 6 Microscopic pictures of the lateral view of $\mathbf{a}$ larva and $\mathbf{b}$ female of Aculops allotrichus. st stylets

\section{Discussion}

Our tests showed that both the production of eggs and their distribution by A. allotrichus females on black locust leaflets were strongly dependent on leaf age. Females laid significantly more eggs on developing leaves (the youngest leaflets, which were folded at the beginning of the test and the young, already unfolded leaflets) than on mature, fully expanded leaves, whereas the greatest number of eggs was deposited on young leaves. The tendency of females to oviposit on the abaxial side of leaflets also increased with leaf age. On the youngest leaves, females distributed similar numbers of eggs on the adaxial and abaxial sides of leaflets, whereas on the fully expanded leaves almost all eggs were placed on their abaxial side.

The preference of herbivorous insects and mites to feed and oviposit on young leaves is often correlated with the relatively high nutritious value and softness of young tissue in comparison with older leaves (Coley 1980; Dąbrowski and Bielak 1978; Wilson 1994; Awmack and Leather 2002; Č́žzek 2005; Chen et al. 2007). The results of our biochemical and morphometric analysis confirm such a tendency in A. allotrichus. Developing leaflets of black locust had elevated levels of free amino acids and total soluble sugars, which are regarded as primary nutritive compounds for insect egg production (Awmack and Leather 2002; Levin et al. 2017). They also had positive effects on mites but this also depended on the mite species and the type of compound and its concentration within the host plant (Dąbrowski and Bielak 1978, Armellsa and Ridsdill-Smith 1994; HuaCai et al. 2000; Ximénez-Embún et al. 2016). From studies on the interactions between three species of Tilia and gall-inducing eriophyoid mites, it was concluded that $T$. cordata leaves create the worst conditions for these mites due to their low content of nutrients (proteins and sugars) in comparison with T. platyphyllos and T. tomentosa (Soika et al. 2017). In our study, the youngest leaves had a similar content of total soluble sugars as the fully expanded leaves. Nonetheless, the concentration of free amino acids was almost twice as high, which, alone, could be responsible for much higher egg production on the youngest leaves in comparison with the mature ones.

Interestingly, the youngest leaves also had a much higher percentage of dry matter in comparison with the young and mature leaves. As shown in the investigation of T. urticae from strawberry and rose (Dąbrowski and Bielak 1978), the effect of higher dry mass on mite fecundity can be positive or negative according to the plant species. A higher content 
of dry biomass (related to lower water content) may make the tissue more suitable for herbivore feeding due to the higher concentration of nutrients per unit of the consumed plant area (Showler 2013). However, the reduced content of water (indispensible for many physiological processes) may also negatively affect the performance of the herbivore arthropod, and make the cell cytoplasm more viscous, and it may also impede its food ingestion using stylets (Showler 2013).

In our study, the youngest and young leaves had similarly high contents of free amino acids. However, the young leaves had significantly greater concentrations of total soluble sugars, which could have, additionally, positive effects on the oviposition of A. allotrichus on that leaf category. As the level of reducing sugars in the present study did not differ among all tested leaves, the other soluble sugars, e.g., sucrose or maltose, or oligosaccharides, apart from free amino acids, could have been responsible for the fact that the highest egg production was on young leaves. Carbohydrates are important sources of energy for herbivore arthropods and both hexoses and disaccharides, e.g., sucrose and maltose, are important phagostimulants (Showler 2013).

The developing leaves of $R$. pseudoacacia also had a significantly higher concentration of phenols than the mature leaves. Phenols play an essential role in plant defence against both biotic and abiotic stress. Many of them act as deterrents, antifeedants or toxins for herbivorous arthropods, negatively affecting their growth and ovipostion (Dąbrowski and Bielak 1978; Schultz 1989; Awmack and Leather 2002; Petanović and Kiełkiewicz 2010a; War et al. 2012). Thus, it remains to be clarified how A. allotrichus females, coupled with phenols and in spite of their increased content in developing leaves, laid a higher number of eggs than on the fully expanded leaves. Similarly, Wilson (1994) did not detect any deleterious effect of increased levels of condensed tannins on the fecundity of two-spotted spider mites on young cotton leaves. Interestingly, some eriophyoid species are reported to tolerate some level of phenols that are induced in plant tissue after their feeding (Soika et al. 2017).

Undoubtedly, more investigations are needed on the interactions between eriophyoid mites and phenols, as well as other toxins within plant tissue. Some herbivorous insects can tolerate the presence of tannins through their absorption by peritrophic membrane in the midgut and the action of sulfactans that reduce the formation of tannin complexes with proteins. Moreover, tannins and other phenolics can also act as phagostimulants for some insects (Schultz 1989; Bernays and Chapman 2000). It must be stressed that we analysed the content of phenols within whole black locust leaves, whereas A. allotrichus feeding is restricted to the epidermal cells of the leaves. Phenols can be present elsewhere in plant tissue including epicuticular waxes, cuticle and cell walls (Hunt and Baker 1980; Weber et al. 1995; Wójcicka 2016). They are produced and frequently stored in the vacuoles of specialized cells whose distribution within plant tissues can differ greatly according to the plant species (Beckman 2000; Chalker-Scott and Krahmer 1989). In R. pseudoacacia, the specialized cells filled with tanniferous content are numerous and they are located subepidermally in the mesophyll (Orlović et al. 2004, Michalska and Łotocka unpubl.), which suggests that $A$. allotrichus may not, or rarely, come into contact with phenols when feeding on leaf epidermis.

A thick outer epidermal cell wall can considerably hamper penetration of leaf tissue by the mouth-parts of herbivorous insects and mites (Tibebu 2018; Ochoa et al. 2011). Thus, herbivores often avoid toughened leaves (Hanley et al. 2007) or, like the tenuipalpid mite Raoiella sp. on palm or Tetranychus urticae (Bensoussan et al. 2016), use stomata to insert their stylets into a leaf. To get through the epidermal cell wall eriophyoids have to exert physical strength (Westphal and Manson 1996; but see also Glas 2014), which may limit 
their feeding on tough leaves or their tougher parts. This may especially refer to the youngest stages of eriophyoids, such as larvae newly hatched from eggs. As our study showed, A. allotrichus females are equipped with stylets that are several times longer than the thickness of epidermal walls of mature leaf blades. Interestingly, the stylets of larvae are only slightly shorter, and appear to be disproportionally long in relation to their body length. However, as the larvae are much smaller than adults, they probably have to expend much more energy and time to insert stylets, especially into tougher leaves. Thus, it could be in the interest of eriophyoid females to secure availability of food for their offspring and deliberately lay eggs avoiding epidermal sites with thicker cell walls. Such a tendency appears to be supported by the data of our morphometric analysis of the black locust leaves. It has revealed that the thickness of the outer epidermal wall not only increased with leaf age but also differed between leaf sides and between main veins and a blade. In the fully expanded leaves of the black locust, on which A. allotrichus reluctantly laid their eggs, the outer epidermal cell walls were ca. twice as thick as on younger leaves. Moreover, leaf blades had much thicker outer cell walls on the adaxial than the abaxial sides, which could also have forced females to lay more eggs on the abaxial sides. Only on the youngest leaves, in which the outer cell walls were generally very thin (for comparison see, e.g., Lees 1984; Onoda et al. 2015), did the eriophyoids accept slightly thicker walls on the adaxial leaf side.

In our study, the outer epidermal cell walls of main veins were much thicker than those of blades. Interestingly, A. allotrichus was observed to feed and lay eggs on main veins, although mostly on the adaxial side of younger leaves (K Michalska, pers. obs.). Adaxial main veins possess shallow depressions, which seem to serve as a sort of protection for eriophyoids. On their adaxial side, the outer epidermal cell walls were much thinner than those on the abaxial side. Thus, the costs connected with drilling through the walls of adaxial veins might have been still lower than the protection benefits served by those veins. In contrast, abaxial main veins were very prominent and had very thick outer epidermal cell walls, which also seemed to limit eriophyoid feeding on them. However, as in other eriophyoid species, e.g., Aculops lycopersici (Massee) or Acaphylla theae (Watt.) (Keifer 1975), females of $A$. allotrichus preferentially deposited eggs along such veins, using the narrow space between the vein and blade to insert their eggs (K Michalska, pers. obs.).

Similar to the various depressions or crevices on leaves, leaf trichomes also appear to be of special value to eriophyoids. Many species prefer leaf pubescence or even stimulate growth of the leaf trichomes (so-called erinea) among which they live (Keifer 1975). In dense leaf trichomes eriophyoids may avoid predation and herbivore competition (Krips et al. 1999; Glas 2014); trichomes may also screen biologically harmful UV-B radiation (Suzuki et al. 2009; Xiao et al. 2017) and keep water droplets off the leaf surface (Gutschick 1999), lowering the chance that eriophyoids will drown or be washed off the leaf surface by rain. Protection against adverse abiotic conditions appears to be especially important on the adaxial side of leaves, and the absence of such protection may explain why many leaf dwelling mites mostly inhabit the abaxial side (Sudo and Osakabe 2011).

As our studies showed, developing leaflets of the black locust tree have very dense trichomes on both sides of blades and veins, which may also provide protection for A. allotrichus females and their eggs. However, the density of trichomes significantly decreases with leaf age. Thus, similarly to the thickening of outer epidermal cell walls, decreasing trichome density may also worsen living conditions on the adaxial leaf surface and force females to deposit more eggs on the abaxial side of leaflets.

In conclusion, leaf age had a significant impact on the production and distribution of eggs by A. allotrichus. The high fecundity of this eriophyoid on still developing leaves seems to be connected with the high content of amino acids and sugars in those leaves, 
although a high density of leaf hairs and thin epidermal cell walls may also favour eriophyoid oviposition.

Along with the development of leaves, females also increased their preference for placing eggs on the abaxial side of leaflets. This preference appears to be connected with exacerbating conditions on the adaxial side: (1) decrease in trichome density which could provide protection for eriophyoid eggs, and (2) a significant thickening of the outer epidermal cell wall (much higher on the adaxial than abaxial side) which may impede the feeding of eriophyoid females and their offspring.

It must be stressed that the eriophoids we tested were collected from a population that developed on only one black locust tree. Similarly, the black locust leaves we used in our experiments and analysis came from only one location. However, both the chemical composition of leaves as well as their pubescence or toughness may depend on many environmental factors, e.g., UV-B radiation, exposure to sunlight, elevation, availability of nutrients in soils and humidity can all affect leaf toughness or pubescence (Osborn and Taylor 1990; Hanley et al. 2007; War et al. 2012; Ximénez-Embún et al. 2016; Xiao et al. 2017). Also, differences in structural traits (e.g., thickness of epidermal cell walls) between abaxial and adaxial sides of $R$. pseudoacacia leaflets may vary according to climate conditions (Rashidi et al. 2012). Therefore, depending on the origin of the eriopyoid population and the site on which the black locust tree grows, egg production and their distribution by $A$. allotrichus on leaflets may differ, and undoubtedly more comparative studies on this aspect of eriophyoid behaviour are needed.

Acknowledgements We thank Prof. M. Kiełkiewicz-Szaniawska for helpful discussion, and two anonymous reviewers for their valuable comments on the manuscript. We also thank K. Szawłowska for trichome counting, E. Znojek for preparation of leaf sections for TEM and B. Michniewska for her assistance in the analysis of amino acids.

Open Access This article is distributed under the terms of the Creative Commons Attribution 4.0 International License (http://creativecommons.org/licenses/by/4.0/), which permits unrestricted use, distribution, and reproduction in any medium, provided you give appropriate credit to the original author(s) and the source, provide a link to the Creative Commons license, and indicate if changes were made.

\section{References}

Amrine JW, Stasny TA (1994) Catalog of the Eriophyoidea (Acarina: Prostigmata) of the world. Indira Publishing House, West Bloomfield

Armellsa AJ, Ridsdill-Smith TJ (1994) Host plant species and carbohydrate supplements affecting rate of multiplication of redlegged earth mite. Exp Appl Acarol 18:521-530

Awmack CS, Leather SR (2002) Host plant quality and fecundity in herbivorous insects. Ann Rev Entomol 47:817-844

Bauerfeind SS, Fisher K (2005) Effects of adult-derived carbohydrates, amino acids and micronutrients on female reproduction in a fruit-feeding butterfly. J Insect Physiol 51:545-554

Beckman CH (2000) Phenolic-storing cells: keys to programmed cell death and periderm formation in wilt disease resistance and in general defence responses in plants? Physiol Mol Plant Pathol 57:101-110

Bensoussan N, Santamaria ME, Zhurov V, Diaz I, Grbić M, Grbić V (2016) Plant-herbivore interaction: dissection of the cellular pattern of Tetranychus urticae feeding on the host plant. Front Plant Sci. https:// doi.org/10.3389/fpls.2016.01105

Bernays EA, Chapman RF (2000) Plant secondary compounds and grasshoppers: beyond plant defenses. J Chem Ecol 26:1773-1794

Bradford MM (1976) A rapid and sensitive method for the quantitation of microgram quantities of protein utilizing the principle of protein-dye binding. Anal Biochem 72:248-254

Călina CD, Mitruţ AO, Turcu SA, Bălăşoiu L, Popescu H (2011) Histo-anatomical data concerning Robinia pseudoacacia L. species (Fabaceae). Acta Med Marisiensis 57:429-431 
Castagnoli M, Laffi F (1985) Aculops allotrichus (Acarina: Eriophyoidea) injurious to Robinia pseudoacacia. Details of biology and systematics. Redia 68:251-260

Castagnoli M, Oldfield GN (1996) Damage and control of eriophyoid mites in crops. Other fruit trees and nut trees. In: Lindquist EE, Sabelis MW, Bruin J (eds) Eriophyoid mites-their biology, natural enemies and control, vol 6. Elsevier, Amsterdam, pp 543-560

Chalker-Scott L, Krahmer RL (1989) Microscopic studies of tannin formation and distribution in plant tissues. In: Hemingway RW, Karchesy JJ, Branham SJ (eds) Chemistry and significance of condennsed tannins. Plenu Press, New York, pp 345-368

Channabasavanna GP (1996) Sugercane, coffee and tea. In: Lindquist EE, Sabelis MW, Bruin J (eds) Eriophyoid mites - their biology, natural enemies and control, vol 6. Elsevier, Amsterdam, pp 631-640

Chatzivasileiadis EA, Sabelis MW (1997) Toxicity of methyl ketones from tomato trichomes to Tetranychus urticae Koch. Exp Appl Acarol 21:473-484

Chen Y, Opit GP, Jonas VM, Williams KA, Nechols JR, Margolies DC (2007) Twospotted spider mite population level, distribution, and damage on ivy geranium in response to different nitrogen and phosphorus fertilization regimes. J Econ Entomol 100:1821-1830

Coetzee JH, Wright MG, Giliomee JH (2009) Anti-herbivore mechanisms of economically important Proteaceae species in the African Cape Fynbos. J Appl Ent 121:367-372

Coley PD (1980) Effect of leaf age and plant life history patterns on herbivory. Nature 284:545-546

Č́žzek L (2005) Diet composition and body size in insect herbivores: Why do small species prefer young leaves? Eur J Entomol 102:675-681

Dalin P, Ågren J, Björkman C, Huttunen P, Kärkkäinen K et al (2008) Leaf trichome formation and plant resistance to herbivory. In: Induced plant resistance to herbivory. A. Schaller (ed.), Springer, Dordrecht, pp 89-105

Dąbrowski ZT, Bielak B (1978) Effect of some plant chemical compounds on the behaviour and reproduction of spider mites (Acarina: Tetranychidae). Ent Exp Appl 24:117-126

Duso C, de Lillo E (1996) Grape. In: Lindquist EE, Sabelis MW, Bruin J (eds) Eriophyoid mites-their biology, natural enemies and control, vol 6. Elsevier, Amsterdam, pp 571-592

Evans GO (1992) Principles of acarology. C.A.B International, Wallingford

Fernández V, Guzmán-Delgado P, Graça J, Santos SS, Gil L (2016) Cuticle structure in relation to chemical composition: re-assessing the prevailing model. Front Plant Sci. https://doi.org/10.3389/ fpls.2016.00427

Fernández V, Sancho-Knapik D, Guzmán P, Peguero-Pina JJ, Gil L, Karabourniotis G et al (2014) Wettability, polarity and water absorption of holm oak leaves: effect of leaf side and age. Plant Physiol 166:168-180

Gall BG, Brodie ED, Brodie ED Jr (2012) Fine-scale selection by ovipositing females increases egg survival. Ecol Evol 2:2763-2774

Gibson RW (1974) Studies on the feeding behaviour of the eriophyid mite Abacarus hystrix, a vector of grass viruses. Ann Appl Biol 78:213-221

Glas JJ (2014) Consequences of russet mite-induced tomato defenses for community interactions. Dissertation, University of Amsterdam, The Netherlands

Gorb EV, Gorb SN (2017) Anti-adhesive effects of plant wax coverage on insect attachment. J Exp Bot 68:5323-5337

Gutschick VP (1999) Biotic and abiotic consequences of differences in leaf structure. New Phytol 143:3-18

Hanley ME, Lamont BB, Fairbanks MM, Rafferty CM (2007) Plant structural traits and their role in antiherbivore defence. Perspect Plant Ecol Evol Syst 8:157-117

Hosseinihashemi SK, HosseinAshrafi SK, Goldeh AJ, Salem MZM (2016) Antifungal and antioxidant activities of heartwood, bark and leaf extracts of Robinia pseudoacacia. BioResources 11:1634-1646

HuaCai Ch, Ning X, ZongMao Ch (2000) On the relationship between content of free amino acid in tea shoot and resistance of tea tree to tea pink mite Acaphylla theae Watt. Acta Phytophylacica Sinica 27:338-342

Hunt GM, Baker EA (1980) Phenolic constituents of tomato cuticles. Phytochemistry 19:1415-1419

Johnson G, Schaal LA (1957) Accumulation of phenolic substances and ascorbic acid in potato tuber tissue upon injury and their possible role in disease resistance. Am Potato J 34:200-209

Kaloo MA, Bhat BA, Rafiqi G (2018) Preliminary phytochemical screening of extracts of Robinia pseudoacacia. Int J Pharm Pharmacol. https://doi.org/10.31531/2581-3080.1000126

Keifer HH (1975) Injurious eriophyoid mites. In: Jeppson LR, Keifer HH, Baker EW (eds) Mites injurious to economic plants. University of California Press, Berkeley, pp 397-547

Kreiter S, Tixier MS, Croft BA, Auger P, Barret D (2002) Plants and leaf characteristics influencing the predaceous mite Kampimodromus aberrans (Acari: Phytoseiidae) in habitats surrounding vineyards. Environ Entomol 31:648-666 
Krips OE, Kleijn PW, Willems PEL, Gols GJZ, Dicke M (1999) Leaf hairs influence searching efciency and predation rate of the predatory mite Phytoseiulus persimilis (Acari: Phytoseiidae). Exp Appl Acarol 23:119-131

Lees GL (1984) Cuticle and cell wall thickness: relation to mechanical strength of whole leaves and isolated cells from some forage legumes. Crop Sci 24:1077-1081

Levin E, McCue MD, Davidowitz G (2017) More than just sugar: allocation of nectar amino acids and fatty acids in a Lepidopteran. Proc R Soc B 284:2016-2026

Levis WH, Elivin -Lewis PF (2003) Medical botany: plants affecting human health. Wiley, Hoboken

Lie S (1973) The EBC-ninhydrin method for determination of free alpha amino nitrogen. J Inst Brew 79:37-41

Lindquist EE (1996) External anatomy and notation of structures. In: Lindquist EE, Sabelis MW, Bruin J (eds) Eriophyoid mites - their biology, natural enemies and control, vol 6. Elsevier, Amsterdam, pp 3-31

Lindquist EE, Oldfield GN (1996) Evolution of eriophyoid mites in relation to their host plants. In: Lindquist EE, Sabelis MW, Bruin J (eds) Eriophyoid mites-their biology, natural enemies and control, vol 6. Elsevier, Amsterdam, pp 277-300

Lindquist EE, Sabelis MW, Bruin J (eds) (1996) Eriophyoid mites their biology, natural enemies and control, vol 6. Elsevier, Amsterdam, p 822

Madanat HM, Al -Antary TM, Zarga MHA (2018) Identification and isolation of the insecticidal compounds from Robinia pseudoacacia L. (Fabaceae). Fresen Environ Bull 27:1838-1849

Mayhew PJ (1997) Adaptive patterns of host-plant selection by phytophagous insects. Oikos 79:417-428

Michalska K, Skoracka A, Navia D, Amrine JW Jr (2010) Behavioural studies on eriophyoid mites-an overview. Exp Appl Acarol 51:31-59

Nalepa A (1928) Zur phaenologie und Entwicklungsgeschichte der Milbengallen. Marcelis 24:87

Nelson N (1994) A photometric adaptation of the Somogyi method for the determination of glucose. J Biol Chem 153:375-380

Nuzzaci G, Alberi G (1996) Internal anatomy and physiology. In: Lindquist EE, Sabelis MW, Bruin J (eds) Eriophyoid mites - their biology, natural enemies and control, vol 6. Elsevier, Amsterdam, pp 101-149

Ochoa R, Beard JJ, Bauchan GR, Kane EC, Dowling APG, Erbe EF (2011) Herbivore exploits chink in armor of host. Am Entomol 57:2-29

Onoda Y, Schieving F, Anten NPR (2015) A novel method of measuring leaf epidermis and mesophyll stiffness shows the ubiquitous nature of the sandwich structure of leaf laminas in broad-leaved angiosperm species. J Exp Bot 66:2487-2499

Orlović SS, Pajević SP, Krstić B, Merkulov LS, Nikolić NP, Pilipović AR (2004) Variability of anatomical-physiological traits in black locust clones (Robinia pseudoacacia L.). Proc Nat Sci Matica Srpska Novi Sad 106:65-79

Osborn JM, Taylor TN (1990) Morphological and ultrastructural studies of plant cuticular membranes. I. Sun and shade leaves of Quercus velutina (Fagaceae). Int J Plant Sci 151:465-476

Petanović R, Kiełkiewicz M (2010a) Plant-eriophyoid mite interactions: cellural biochemistry and metabolic responses induced in mite-injured plant. Part I. Exp Appl Acarol 51:61-80

Petanović R, Kiełkiewicz M (2010b) Plant-eriophyoid mite interactions: specific and unspecific morohological alternations. Part II. Exp Appl Acarol 51:81-91

Putra NS, Yasuda H, Sato S (2009) Oviposition preference of two hoverfly species in response to risk of intraguild predation. Appl Entomol Zool 44:29-36

R Development Core Team (2016) R: a language and environment for statistical computing. R Foundation for Statistical Computing, Vienna

Rashidi F, Jalili A, Kafaki SB, Sagheb-Talebi K, Hodgson J (2012) Anatomical responses of leaves of Black Locust (Robinia pseudoacacia L.) to urban pollutant gases and climatic factors. Trees 26:363-375

Resetarits WJ Jr, Wilbur HM (1989) Choice of oviposition site by Hyla chrysoscelis: role of predators and competitors. Ecology 70:220-228

Segado P, Domínguez E, Heredia A (2016) Ultrastructure of the epidermal cell wall and cuticle of tomato fruit (Solanum lycopersicum L.) during development. Plant Physiol 170:935-946

Schultz JC (1989) Tannin-insect interactions. In: Chemistry and significance of condennsed tannins. Hemingway RW and Karchesy JJ (eds) Plenu Press, New York, pp 417-433

Showler AT (2013) Water deficit stress-host plant nutrient accumulation and associations with phytophagous arthropods. In: Vahdati K (ed) Abiotic stress-plant responses and applications in agriculture. IntechOpen, London, pp 387-410 
Stipanovic RD (1983) Function and chemistry of plant trichomes and glands in insect resistance. Protective chemicals in plant epidermal glands and appendages. In: Hedin PA (ed) Plant resistance to insects, ASS Symposium Series, vol 208. American Chemical Society, Washington, pp 69-100

Soika G, Tomczyk A, Kozak M (2017) Biochemical reaction of Tilia leaves on infestation by some species of gall-inducing eriophyoid mites. Int J Acarol 43:16-21

Sudo M, Osakabe M (2011) Do plant mites commonly prefer the underside of leaves? Exp Appl Acarol $55: 25-38$

Suzuki T, Watanabe M, Takeda M (2009) UV tolerance in the two-spotted spider mite, Tetranychus urticae. J Insect Physiol 55:649-654

Thomson JN (1988) Evolutionary ecology of the relationship between oviposition preference and performance of offspring in phytophagous insects. Entomol Exp Appl 47:3-14

Tibebu B (2018) Defense mechanisms of plants to insect pests: from morphological to biochemical approach. Trends Tech Sci Res 2:555584

War AR, Paulraj MG, Ahmad T, Buhroo AA, Hussain B, Ignacimuthu S, Sharma HC (2012) Mechanisms of plant defence against herbivores. Plant Signal Behav 7:1306-1320

Weber B, Hoesch L, Rast DM (1995) Protocatechualdehyde and other phenols as cell wall components of grapevine leaves. Phytochemistry 40:433-437

Westphal E, Manson DCM (1996) Feeding effects on host plants: gall formation and other distortions. In: Lindquist EE, Sabelis MW, Bruin J (eds) Eriophyoid mites-their biology, natural enemies and control, vol 6. Elsevier, Amsterdam, pp 231-242

Wilson LJ (1994) Plant-quality effect on life-history parameters of the twospotted spider mite (Acari: Tetranychidae). J Econ Entomol 87:1665-1673

Wójcicka A (2016) Effect of epicuticular waxes from triticale on the feeding behaviour and mortality of the grain aphid, Sitobion avenae (Fabricius) (Hemiptera: Aphididae). J Plant Prot Res 56:39-44

Xiao K, Mao X, Lin Y, Xu H, Zhu Y, Cai O, Xie H, Zhang J (2017) Trichome, a functional diversity phenotype in plant. Mol Biol 6:1-6

Ximénez-Embún MG, Ortego F, Castañera P (2016) Drought-stressed tomato plants trigger bottom-up effects on the invasive Tetranychus evansi. PLOS ONE. https://doi.org/10.1371/journal.pone.0145275

Yemen EW, Willis AJ (1954) The estimation of carbohydrates in plant extracts by anthrone. Biochem J 57:508-514

Publisher's Note Springer Nature remains neutral with regard to jurisdictional claims in published maps and institutional affiliations. 